\title{
The Liverpool Meeting of the British Association.
}

\author{
Local Arrangements.
}

$A^{N}$ elaborate programme of excursions to places of interest and visits to works has been arranged by the Local Committee. Dealing first with the general excursions, on Thursday, September I3, it is intended that a visit shall be paid to the biscuit works of Messrs. W. and R. Jacob and Co., Ltd., to the United Alkali Works at Widnes, the flourmills of Messrs. W. Vernon and Sons, Ltd., and the Liverpool Corporation electric power-station, when some of the largest and most up-to-date plant will be inspected. The White Star Line is also inviting a party to view the s.s. Adviatic. On Friday, September I4, visits are arranged to Messrs. Bryant and May's match works, to the dyeing and cleaning works of Messrs. Johnson Bros., I.td., and to the shipbuilding yards of Messrs. Cammell Laird and Co., Ltd. The Cunard Steamship Co. is inviting a party to inspect the s.s. Franconia.

On Saturday, September I 5, there will be a wholeday excursion to Chester and the River Dee, including a visit to Eaton Hall, by kind permission of the Duke of Westminster. Another whole-day trip will be to the Dolgarrog works of the Aluminium Corporation, Ltd., the party, after inspecting the works, proceeding to Bettws-y-Coed and the Snowdon district. A visit, also occupying the whole day, has been arranged to the Liverpool Waterworks at Lake Vyrnwy.

Of a more general type there will be a day excursion to the Isle of Man, and also by sea to Llandudno and Beaumaris. There will also be a two-day tour (Saturday and Sunday) to the Lake District. On Sunday, September I6, there will be a general excursion by sea to Llandudno and Beaumaris.

On Monday, September I7, visits will be paid to one of the works of the British Insulated and Helsby Cables Co., Ltd., Messrs. Lever Bros.' Soap Works at Port Sunlight, and to the works of Meccano, Ltd., and to the Union Cold Storage, Ltd. A party will also be shown the Liverpool housing scheme, and the Liverpool Salvage Association is inviting those interested to view their plant. The Booth Steamship Co., Ltd., is inviting a party to inspect the s.s. Hildebrand.

On Tuesday, September I8, a party will visit the Gladstone Dock and other works of the Mersey Docks and Harbour Board, the Llay Main Colliery near Wrexham, Planter's margarine works at Bromborough Pool, and the large bobbin works of Messrs. Wilson Bros. at Garston.

Of the sectional excursions at present arranged, Section A will visit the Automatic Telephone Manufacturing Co., Ltd., the British Oxygen Co. (Bootle works), and Stonyhurst College; Section B, the United Alkali Co.'s works at Widnes, the Highfield Tannery at Runcorn, Price's Patent Candle Co. at Bromborough, the lactose factory at Haslingden near Crewe, and Messrs. Joseph Crosfield and Co.'s works at Warrington.

Section $\mathrm{C}$ will go to Hall Road and Crosby on the north of Liverpool, Storeton Quarries, Burton Point and North Wirral, Lake Vyrnwy district, parts of Flintshire, the Lea Green Collieries and Brick Pits, and Scarth Hill and Skillaw Clough.

Section $\mathrm{D}$ is proposing to go a dredging expedition in Liverpool Bay, and to Delamere Forest. Section E is visiting the Liverpool Docks, Storeton, Burton Point and North Wirral, and a river trip to the Eastham Locks of the Manchester Ship Canal, and down the Mersey to the Crosby Channel.

Section $\mathrm{F}$ intends to visit the Liverpool Docks and the Cotton Exchange. Section $G$ has arranged one excursion only, and that is to the Gladstone Dock. Section $\mathrm{H}$ will inspect the Roman remains at Chester, and will also visit Ince Blundell.

Section I has arranged no sectional excursions.

Section J has one excursion only, namely, to Rainhill, where the County Lunatic Asylum is situated.

Section $\mathrm{K}$ is planning to visit the Craven limestone district, Mr. Bulley's gardens at Neston, and the West Lancashire sand dunes near Freshfield. Section $\mathrm{L}$ has arranged no excursions. Section M will visit Wirral Farms and Messrs. Gartons, Ltd., at Warrington, and Haslington and the Nantwich district.

Large as this list of sectional excursions appears, if one is to judge from the experience of previous meetings it will be found to have increased by the date on which the meeting commences.

A list of all these excursions and visits will be sent, a short time before the meeting, to members who have intimated their intention of coming to Liverpool, and it will greatly facilitate the work of the Local Secretaries if members will intimate in advance which excursions they would wish to join.

At the close of the meeting in Liverpool there will be an excursion to the Isle of Man, leaving Liverpool on Wednesday, September I9, and returning on Monday, September 24. The party will have an opportunity of visiting all places of scientific interest in the island, but probably members of Sections $\mathrm{E}$ and $\mathrm{H}$ will find most to study. A special committee in the Isle of Man is making all arrangements, and details will, it is hoped, be completed by the opening day of the meeting in Liverpool.

Although perhaps it does not so much concern the actual members of the Association, yet a definite item in the programme of the meeting is the series of public lectures. The number of these it is proposed to give in Liverpool will be greater than in any town previously visited by the Association, and further, one will be given in Bootle, Wallasey, Birkenhead, Runcorn, Warrington, Wigan, and, St. Helens, while two lectures to young people will be given in Liverpool and one in Birkenhead and Warrington. It is the hope of the Local Committee that these lectures will prove a great success, and so develop one of the prime objects of the Association, namely, to promote interest in science and its applications.

ALFREN HOLT.

\section{International Hydrography.}

M ANY abortive attempts were made before the War to found an international hydrographic organisation, but success was not achieved until after the War, when a conference was held in London, in I9r9, at the invitation of the British Admiralty, with the cordial support of the French hydrographic office. Twenty-one states were represented at the conference, invitations having been sent to all countries likely to be interested, with the exception of the Central Powers, Russia, and Turkey. As a result an International Hydrographic Bureau was instituted in I92 I, and all the States represented at the conference have now associated themselves with it. The Bureau has its official seat at Monaco. Soon after its institution it became affiliated to the League of Nations, and it uses the official languages of the League, namely,

NO. 2808, VOL. 1 I 2 ] 